conservative theory but one that for decades has explained the particular ways that black women experience racialized sexism and more.

Lindsay is not against ABMSs and encourages them as long as they offer antisexist curricula and support progressive education for black boys. Public education is a right; however, institutionalized racism influences the ways in which black boys and black girls experience education in the United States. Lindsay details how public education is mired with problems from poor funding, inexperienced teachers, and heightened poverty. Coupled with neoliberal arguments supporting ABMSs, we can see why some want to support single-sex education.

The connection between masculinity and racism has caused significant heartache for black boys and their families. Masculinized racism curtails black boyhood by portraying them and their actions under a negative light. Black boys need a fair shot at education but face multiple roadblocks. The appendix includes an up-to-date list of ABMSs that have been proposed or established. We should not be surprised that during the last decade, more black parents are homeschooling their children for the same reason that others choose ABMSs.

In a Classroom of Their Own is interdisciplinary and is useful for reading lists in political science, gender studies, sociology, African American studies or black studies, and education. The book is suitable for both the undergraduate and graduate levels. Overall, Lindsay offers rich citations in each chapter demonstrating extensive research and expertise in this topic and many related areas. This book is a must-read for scholars interested in education, single-sex education, a history of intersectionality, and feminist politics.

Janni Aragon is the Director of the Technology \&. Society Program at the University of Victoria: jaragon@uvic.ca

\title{
Vexy Thing: On Gender and Liberation. By Imani Perry. Durham: Duke University Press, 2018. 304 pp. \$26.95 (paperback), $\$ 99.95$ (hardcover).
}

doi:10.1017/S1743923X19000680, e8

Natasha Behl

Arizona State University

Imani Perry's Vexy Thing: On Gender and Liberation is a sophisticated mapping of patriarchy from the Enlightenment to the present. Perry 
focuses attention on the "structure of patriarchy... [and] its gaps, its failures, and its injustices when it comes to the treatment of those under patriarchal authority" (17). She divides the book into two sections: the first section is a historically based conceptual account of the foundations of patriarchy rooted in property, personhood, and sovereignty, and the second section is a mapping of the shifts in patriarchy during the hypermedia neoliberal age. Perry suggests that in the current neoliberal age there is a "doubling of inequality" as "[t]he old architecture of patriarch through property, personhood, and sovereignty remains, but there are fewer absolute exclusions yet more intensive competitive demands that disadvantage those who were once absolutely excluded" (104). Vexy Thing's dual focus - the historical and the contemporary - makes it an essential read for anyone who is interested in understanding gender and gendering in the current vexed political moment.

Vexy Thing uses stories and vignettes to focus attention on "the men who could not be patriarchs, the people who could be neither patriarch nor lady, the captured and the excluded" (6). Perry acknowledges that her use of "story and vignette, along with description, theorization, and analysis, is admittedly an 'odd' structure, at least according to the conventions of academic writing" (6). As someone who functions on the margins of my discipline (Behl 2019), I appreciate the "odd" structure of Vexy Thing and believe it is one of the major contributions of the book. Through a careful reading of sources from nineteenth-century slavery court cases to writings by Toni Morrison and Audre Lorde and art by Kara Walker and Wangechi Mutu, Perry reveals the complex structure of patriarchy, its rules and exceptions, and its states of exception (6). These rigorous readings function as models of how to conduct liberation feminist critique while also inviting readers into a dialogic conversation that encourages them to conduct such critiques in their own daily lives, from their engagement with digital media and technology to their experience of the security state. Through her readings of both visual and literary art, Perry explores art as a philosophical project that disrupts current relations of power and opens up the possibility for more ethical social and intimate relations $(12,245)$. In doing so, she advocates for the primacy of liberation feminist praxis through witchcraft and art making (176), which are collective, communal, and soulful in contradistinction to market logic and the neoliberal and liberal subject (207).

I find Vexy Thing's two Interludes - "Interlude 1: How Did We Get Here? Nobody's Supposed to Be Here" and "Interlude 2: Returning to 
Witches" - deeply powerful. In Interlude 1, Perry explains that the core task for a critical understanding of patriarchy is "to embrace the monstrosity, not the celebrity; the monstrosity, not the representative; the monstrosity, not the ideal. To embrace the monstrosity is to wrestle with the world from the status of the outside. The task is hard and demands that we read the world we occupy rigorously" (97). In Interlude 2, Perry returns to the figure of the witch and asks readers to "rest our thoughts, at least for a moment, on their symbolic value for feminist thought... [as a way] to make our way out from under the force of patriarchy on our minds and will" (172). In her historic and contemporary readings, Perry demonstrates that liberation feminism is both a way to read, map, and make sense of patriarchy, and a way to get out from under the power of patriarchy, even if only momentarily. The point for Perry is to "recuperate" the contingent energy signified by the witch, "restoring it to our social and political imaginary" (175).

In chapter 7, Perry asks, "How do we make space for ruptures in the rules of patriarchy that are not circumscribed to market winners or the individualized commodity and instead open up new forms of relations for more of us and in our analog existences?" (203). In response, in chapter 8 , she turns to art as a way "to pull us beyond the obsession with self-branding that marks neoliberalism" (245). She notes, however, that the art world is squarely part of the neoliberal marketplace, yet she finds that "If art itself does its work well, it has a life beyond its markets" (245).

Perhaps some readers of Vexy Thing might wonder if law - not witchcraft, art, and literature - might be a more viable way of achieving gender liberation. Perhaps other readers might ask if liberation feminism - even one focused on ethics and praxis and rooted in witchcraft, art, and literature - can perpetuate the very patriarchy that Vexy Thing is trying to dismantle. Perhaps still others might wonder to what extent Vexy Thing can capture the lived experience of the nonperson/noncitizen/subaltern when it focuses so heavily on the lived experience of those in the United States. I, too, share these thoughts and questions. Yet, I am drawn to Vexy Thing and its promise of liberation feminism that treats "'feminism' as a verb... as a diachronic poesis of living in politics that is ever changing, uncertain, and vexed but that also, we hope, will bring us closer to freeing us all" (253).

Natasha Behl is Assistant Professor in the School of Social and Behavioral Sciences at Arizona State University: nbehl@asu.edu 


\section{REFERENCE}

Behl, Natasha. 2019. "Mapping Movements and Motivations: An Autoethnographic Analysis of Racial, Gendered, and Epistemic Violence in Academia." Feminist Formations 31 (1): 85-102.

\section{Black Feminism Reimagined: After Intersectionality. By Jennifer C. Nash. Durham: Duke University Press, 2019. 184 pp. $\$ 23.95$ (paperback), \$89.95 (hardback)}

doi:10.1017/S1743923X19000692, e9

\section{Pearl K. Dowe \\ Oxford College, Emory University}

What happens when the theoretical analytic developed by black women to resist the erasure of their experiences and to critique hostile space within the academy becomes a buzzword to signify an ongoing chase for diversity, inclusion, and equity? In Black Feminism Reimagined, Jennifer C. Nash explores how black feminism has responded and should respond to the use of intersectionality, which is grounded in the experience of black women but has become the center of an academic space that has shown a disinterest in the experiences and protection of black women. The paradox of the "success" of intersectionality became evident to Nash as she saw how intersectionality became a constant presence in university strategic plans and mission statements as well as a core value in women's studies departments across the country. She also witnessed how her students had encountered the term or idea of intersectionality prior to taking gender-related courses but remained unfamiliar with the black feminist work that birthed the analytic.

For Nash, black feminism is an "affective project - a felt experience - as much as it is an intellectual, theoretic, creative, political, and spiritual tradition" (3). Because intersectionality has become central to feminist thought and women's studies, the contemporary affect of black feminist practice is defensiveness, in which black feminism has become a type of protective police occupied with the usage and circulation of the term and of black feminism itself. Nash contends that only by letting go of the effort to make intellectual work controlled and protected property can black feminists reimagine the 